in the case of urticaria, angio-neurotic oedema, and the various food idiosyncrasies. Convulsions may be caused by protein ingestion, and, indeed, this is a very usual cause of convulsions in children.

My theory differs from that of anaphylaxis, which has been generally accepted to explain various food idiosyncrasies. In anaphylaxis a preliminary sensitization is required, while my theory maintains that the metabolism of the individual is inadequate. Such an inadequacy for the metabolism of nitrogenous food is most usually inherited, but further damage can be prevented by appropriate diet. The protein poison may act directly on the tissue cells of the nucous membrane or the skin, causing, for example, in the one case bronchitis or colitis, in the other such a disease as eczema. Or again, it may act indirectly, as, for example, through the endocrine or nervous system.

It is impossible in this short paper, which I wish to devote to migraine, to discuss fully the pathogenesis of protein poison manifestations, but since heredity plays such an important part in the etiology of migraine, this at any rate must be considered. The old French school represented by Trousseau, Bouchard, and Dieulafoy laid great stress upon what they called the lithaemic diathesis, and insisted on the close relationship and inheritability of gout, asthma, eczema, migraine, epilepsy, and lithiasis. They also noted the frequent occurrence of cancer in certain families which had this lithaemic diathesis. They failed to see, however, that the real basis of the heredity is a damaged protein metabolism in which protein poison manifestations can take place in any tissue or organ of the body, so producing the diseases which they attributed to lithaemic diathesis. The disease and its symptoms depend entirely upon the site of the manifestations. Each cell of the body is an individual chemical laboratory and plays a part in the general metabolism.

I consider it is quite justifiable to assume that the molecular arrangement of the cell structure, and the characteristics of the cell, upon which depends its ability to function properly, are inherited in the same manner as the general physical characteristics of the individual are inherited.

Migraine occurs in individuals who have inherited a damaged metabolism for nitrogenous foods, and I have chosen it as the subject of this paper because the remarkable results that $I$ have obtained in its relief by the practical application of the protein poison theory have been so conclusive as to leave no doubt in my mind as to its truth and value.

Headache is one of the commonest forms of protein poison manifestation. The headaches caused by protein poison vary in severity from the mildest headache to the severest forms of typical migraine. The etiology of all functional headaches is the same. In migraine we have, however, the typical inherited insufficient protein metabolism. It is true that other causal factors, such as eye-strain, may act in producing headache, but they are seconciary causes and are incapable of producing migraine if the essential cause is removed. It is quite easy to prove that protein poison is the essential cause of headache by letting a patient resume the articles of diet the omission of which caused the headache to cease. It is true, however, that some patients on a low protein diet will acquire a certain degree of tolerance for the very foods that formerly caused headache. Other patients, however, will never be able to take cortain protein foods. It is most important to know that extracts from protein foods such as soups and gravies, and fruit extracts also, though they contain no protein, contain the protein poison and are very potent in causing headache; indeed, one reason why dieting has been unsuccessful in the past is because meat extracts and fruit and fruit juices have not been suspected.

I have found that skin tests are unreliable, and the quickest and best way to ascertain what foods are deleterious in each individual case is to commence with a liet free from protein, especially animal protein, and then to build up gradually a suitable diet therefrom.

The foods which I have found potent in causing headache are meat, fish, poultry, game, and extracts such as soups and gravies made from them; eggs, milk, and cheese; fruit and fruit juices; coffee, tea, chocolate, and alcohol; and, among the vegetables, tomatoes and mushrooms. This at the first glance seems to leave nothing to eat but cereals, butter, and vegetables; and, indeed, this is the basic diet upon which to put a patient for a few weeks until his headaches are controlled. I use a diet of polished rice, butter, toast, a few green vegetables, and water.

Many patients show immediate improvement, but some are worse the first week-those who formerly had occasional headache having it continuously. This is especially true of immoderate coffee drinkers. The second week there is considerable improvement, and in the third week the majority of patients are distinctly better. In women there is usually a recurrence of headache at the first menstrual period, but after a month or two they have no more headache, not even at the menstrual period.

So soon as the headache is distinctly improved the diet should be amplified, at first with other vegetables, then by a small amount of meat once a day. Milk may be used in the cooking (many patients cannot take raw milk in any quantity) and different articles of nitrogenous food added from time to time until the tolerance for different foods is ascertained. Very few subjects of migraine can take meat soups, fruits, or eggs in any quantity. Sweetbreads, mushrooms, tomatoes, and choeolate usually must be banned entirely. With some it is necessary to omit a single article only, such as eggs. Every article of nitrogenous nature must be suspected until proved to be harmless in the particular case. The protein of cereals and regetables is usually well borne.

It must be remembered that erery food of nitrogenous nature has its specific protein. Some patients who cannot take beef can take lamb or chicken. I have had patients who were very susceptible to such proteins as unpolished rice, almonds, and peppermint. Some can take tea with impunity, but cannot take coffee; as a rule, however, most can take a fairly generous diet if certain particular proteins are omitted.

It is best that all sufferers from migraine should be on a fairly low protein diet. I believe also that the less carbohydrate and fat that is consumed the greater is the ability of the patient to metabolize protein. This may explain why some cases of migraine have been relieved by adopting a low carbohydrate or low fat diet; but $I$ am convinced from my experience that the protein is the real causal agent of migraine.

I am well aware that the statements I make will seem somewhat dogmatic, but $I$ am convinced of the truth of them. A single trial of this method in the most obstinato case of migraine will convince the most sceptical, and the success of his treatment will soon tempt him to apply tho theory in other cases of functional disease, where it is chiefly applicable. Diseases in which organic change has already begun cannot be cured by diet, but the protein poison theory throws light upon their etiology and therefore suggests the possibility of preventing all the diseases of metabolism. It gires a new riewpoint in such serious diseases as nephritis, arterio-sclerosis, and even tumour growth.

\section{CANCER OF THE BREAST:}

\section{RECURRENCE 31 YEARS AFTER OPERATION.}

$\mathrm{BY}$

\section{F. J. STEWARD, M.S., F.R.C.S.,} SURGEON TO GUY'S HOSPITAL.

I MAKE no apology for publishing a note of this casc owing to its outstanding interest in its bearing on the age-long question, When is cancer cured?

I saw the patient a short time ago with Dr. James Bromley of Sible Hedingbam. Hel history was as follows :

Mis. R., aged 81 year's, was operated upon for cancer of the left breast thirty-one years ago by the late Sir Henry Butlin. She had no further trouble until a few months before I saw her, when Dr. Bromley discovered three small hard nodules beneath the skin of the left chest in the immediate neighbourhood of the scar of the operation wound. These had slowly increased in size. During the 
past two months some enlargement of the veins orer the front of the left chest had appeared, and the patient complained of some degree of breathlessness and of pain in the chest.

When I examined her I found three hard nodules, as Dr. Bromley had observed. These were each about half an! inch in diameter, vere situated beneath the skin, and were not fixed either to the skin or to the deeper parts. These nodules were each close to the operation scar and were separated from one another by about an inch and a half. The front of the chest to the inner side of the scar was somewhat prominent, and a few dilated reins were to be seen. There was also some degree of dullness on percussion over the prominent area. The patient was rather breathless and looked ill, but not extremely so. She, however, died the same night.

There can be no reasonable doubt that the superficial nodules were carcinomatous, and that they had appeared quite recently, for Dr. Bromley was satisfied that they were not present much more than two months before my examination. There was certainly also a growth in the mediastinum, which had probably been present for some time, and which presumably caused the patient's death.

In spite of the interval of no less than thirty-one vears there can be little doubt that the subcutaneous nodules and the mediastinal growth were directly connected with the original growth in the breast, and, if this is so, it would appear that carcinoma cells may lav dormant in the tissnes for a period of upwards of thirty vears, and for all this time give no sign, and then simultaneously, in at least four separate and distinct sites, once more become active.

What was the exciting cause of this fresh outhurst of activity? Whatever it was, apparently it must have been general rather than local, otherwise the fact of four separate and independent foci becoming active at the same time cannot be explained, for, as regards the three subcutaneous nodules, as has already been mentioned, these were separated from one another by apparently healthy subcutaneous tissue, and were, moreover, all of practically the same size, and hence began to grow at the same time.

\section{DIAGNOSTIC VALUE OF THE SUGAR CONTENT OF THE CEREBRO-SPINAL FLUID IN ENCEPHALITIS LETHARGICA. BY}

H. A. COOKSON, M.B., Ch.B., F.R.C.S.T.,

PATHOLOGIST AND BACTERIOLOGIST, ROYAL INFIRMARY, SUNDERLAND.

So far back as 1917 it was observed by von Economo that the sugar content of the cerebro-spinal fluid was increased in many, if not in all, cases of encephalitis lethargica. During the past year I have examined a series of specimens of cerebro-spinal fluid withdrawn from patients provisionally diagnosed as suffering from encephalitis lethargica, and in all cases in which this diagnosis was finally confirmed the sugar content of the fluid was found to be increased.

The method employed for the estimation of this sugar content was that advocated by Maclean ${ }^{1}$ for the determination of the sugar content of the blood: it was found to be satisfactory in over a hundred examinations of cerebrospinal fluid in addition to those recorded in the accompanying table. By this method the figure for apparently healthy fluids was found to be within the range of 0.065 to 0.08 per cent., whilst, using Bang's microscopic method, ${ }^{2}$ the average figure obtained was 0.072 . Although it may be conceded that the method of Bang or Folin-Wu, or again the modification of the Benedict-Osterberg procedure used by Alpers ${ }^{3}$ and others, would have given more accurate results, yet Maclean's method is nowadays so well known to many general practitioners, owing to the modern discoreries in connexion with the diagnosis and treatment of diabetes, and can be so easily performed with a reasonable degree of accuracy, that any considerable departure from the normal is readily appreciated.

It will be observed from examination of the accompanying table that in almost every case finally diagnosed as encephalitis lethargica the sugar content was definitely

increased abore the normal, and that in no instance was there any diminution. Increased sugar values occur moubtedly in certain other diseases, yet the absence of a decrease is, I think, a valuable point in diagnosing this condition from the groul of other meningeal diseases, especially from tuberculous meningitis. The failure of 1 c.cm. of cercbro-spinal fluid to reduce $0.25 \mathrm{c.cm}$. of Fehling's solution would also probably be of value as a criterion in cases in which an estimation of the amount of sugar present was inipracticable. Such a procedure, br excluding encephalitis lethargica, should be of considerable utility, whilst the indication in this way of a definite increase in the sugar content would go far towards establishing a positive diagnosis.

Table shouing Sugar Content (percentages) of the Cerebro-spinal Fiuid in Encephalitis Lethargica and Simular Diseuses. (The initials are those of the patients examined.)

Encephalitis lethargica.

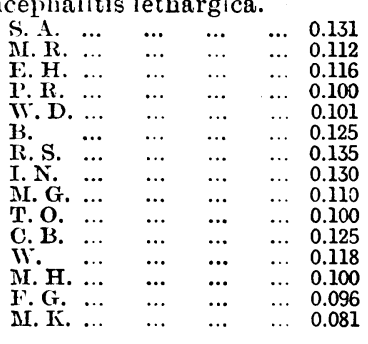

Arerase smar content $=0.112$

'T'uberculous meningitis. S. A. N.
E. A. …
L. W. $\cdots$
II. D. ...

Averase slicilr content $=0.050$ Other meningeal infectious.

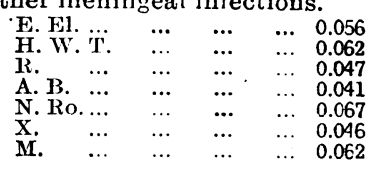

Average sugar content $=0.054$

Other conditions clinically like encephalitis letbargica.

$\begin{array}{lccccc}\text { R. A. } \ldots & \ldots & \ldots & \ldots & 0.080 \\ \text { S. } & \ldots & \ldots & \ldots & \ldots & 0.078 \\ \text { E. J. } & \ldots & \ldots & \ldots & \ldots & 0.074 \\ \text { S. B. } & \ldots & \ldots & \ldots & \ldots & 0.081 \\ \text { I. N. } & \ldots & \ldots & \ldots & \ldots & 0.02 \\ \text { C. H. } & \ldots & \ldots & \ldots & \ldots & 0.075 \\ \text { G. G.* } & \ldots & \ldots & \ldots & \ldots & 0.100\end{array}$

Average sugar content $=0.080$

In nearly every case of encephalitis lethargica in the series the eye sign described by Thorp ${ }^{4}$ was present-a valuable diagnostic point.

REFERENCES.

Maclean : Morlern Methods in the Diagnosis and Treatment of Glycosuria and Diabetes. "H. Kabler: Wien. klin. Woch., 35, 8, 1922, 3 Alpers ct al.: MH:DiCIL JOTRN.L, 1921, vol. ii, p. 508 .

\section{ftemaranda : MEDICAL, SURGICAL, OBSTETRICAL.}

THROMBO-ANGIITIS OBLITERANS.

Is view of the recent article on thrombo-angiitis obliterans, by Telford and Stopfoid (British Medical Jourvil, December 6th, 1924, p. 1035), the following case is of interest.

A carter (British), aged 43, had been subject for twelve months to pain in the right calf and foot after walking the pain subsided on resting, but returned on further exercise. The condition was worse in cold weather. He first noticed change in the colour of his tces seven weeks prior to admission to hospital; there was no history of injury to the foot.

Examination rerealed dry gangrene of the third toe and part of the adjacent toes, the gangrene extending half-way up the dorsum of the foot. Palpation revealed pulsation in the femoral artery, extending to the apex of Scarpa's triangle; elsewhere in the limb no pulsation could be detected. Cutaneous sensation of the right foot was impaired, and there was marked wasting of the muscles of both lower limbs. There was slight oedema of the left foot. His general condition was good; nothing abnormal was detected in heart, lungs, or urine; the Wassermann reaction was negative.

A supracondylar amputalion was performed. The tissues of the stump were rather anaemic; haemorrhage was practically absent: the popliteal artery was occluded by clot and was closely adherent to the surrounding tissues. Further dissection showed thrombosis of the anterior and posterior tibial vessels.

Microscopical examination vielded findings similar to those rccorded in the paper referred to.

My thanks are due to Dr. J. F. Hodgson for permision to publish this case.

H. J.AFÉ, M.R.C.S. Ilunse-Surgeon, Royal Ifalifax Infirmary. 